\title{
САВРЕМЕНЕ СТУДИЈЕ КУБАНСКЕ КУЛТУРЕ: ФЕРНАНДО ОРТИС И ПОЈАМ ТРАНСКУЛТУРАЦИЈЕ
}

\begin{abstract}
Апстракт: Основу западноевропских, а несумњиво и источњачких култура, чине процеси сусрета, комуникације, мешања, прожимања и узајамног саображавања. Осим на европском континенту, ова појава видљива је посебно у културама које су у политичком и социјалном смислу биле у односима доминације и субмисивности, као део колонијалног система. При додиру различитих култура селективно се преузимају махом одређени елементи, којима се дају нови облици, нова значења или другачије функције. Међу првим теоретичарима латиноамеричке културе, кубански антрополог, историчар, етнолог, криминолог, адвокат, лингвиста, политичар и дипломата Фернандо Ортис Фернандес, у књизи Кубанско конитрайункйиране gувана и шећера истакао је значај појма „транскултурација“. Овај појам био је у центру Ортисовог истраживања капацитета тзв. периферних култура да стварају интеркултурне фузије кроз сусрете и преузимања одређених елемената уместо да некритички или пасивно асимилују културе и(ли) њихове сегменте. Транскултурација је у основи кубанске историје будући да је пратећи елемент развоја културе и друштва од првих становника до савременог доба. Иако се одвија по фазама, овакав вид фузије подразумева расна, друштвена, културна, обичајна, цивилизацијска и друге врсте мешања и дијалога. У складу с наведеним поставкама, у раду су представљени основни елементи концепта транскултурације, који Ортис у свом обимном есеју не само теоријски и методолошки образлаже већ кроз заступљеност две важне пољопривредне културе на кубанском тлу, дувана и шећера, настоји да покаже симболичну игру моћи, специфичности друштвене историје и проблеме националног идентитета.

Кључне речи: Фернандо Ортис, транскултурација, кубанска култура, етнографске студије, студије латиноамеричке културе
\end{abstract}

\section{Увод}

Основу западноевропских, а несумњиво и источњачких култура, чине процеси сусрета, комуникације, мешања, прожимања и узајамног саображавања. Осим на европском континенту, ова појава видљива је у културама широм света, а посебно на оним меридијанима и у друштвеним заједницама које су у политичком и социјалном смислу биле у односима доминације и субмисивности, као део колонијалног система. По речима Ђуре Шушњића (2015: 440), током времена, у оваквој врсти сусрета култура по правилу 
долази до тзв. акултурације, која подразумева промене у изворној култури и културном обрасцу. Међутим, на ову врсту неизбежног дијалога не треба гледати као на недостатак или дефект, болесна и неприродна стања већ као на прилику за обогаћење оним што одређена култура није имала у свом спектру карактеристика. Дакле, при додиру различитих култура селективно се преузимају неки елементи, којима се дају нови облици, нова значења или другачије функције. Снага утицаја креће се од тзв. снажније или развијеније културе ка мање снажној или мање развијеној, премда прималачка култура никад није пасивна већ поруке из давалачке културе претвара у познате симболе, дајући елементима специфичан и препознатљив оквир, сврху и значење. Шушњић (2015: 440) примећује да је акуліиурација данас већ застарео појам у студијама културе и антропологије, будући да су у употреби релевантнији и језгровитији термини, попут „додира култура“, „прожимања култура“, „култура у дијалогу“ итд.

У оквирима постколонијалне критике у претходним деценијама може се издвојити неколико важних питања и проблемских блокова:

a) проучавање граница насталих култура, по правилу уз присуство вредносног суда и потребе за успостављањем хијерархијских структура;

б) појам транскултурације (transculturación), који разматра, између осталог, специфичну појаву сусрета култура „доминантног“ језика или културе, чији елементи постају део локалног, „субмисивног“ језика и културне заједнице. Стога најважнији елементи анализе у оквиру овог појма постају феномени хибридности, конфликта или тензије који се јављају између локалних језика или културе и „спољашњих елемената“ колонизаторског карактера, или између локалне културе и оне која је с временом добила такав статус иако није део доминантне, „освајачке“ културе итд;

в) настанак и развој студија у чијем је центру геокултуролошка визија, представљена у тексту Оријеніиализам (Orientalism, 1978) Едварда Саида (Edward Said, 1935-2004), у којем се анализира слика „оријента“ из перспективе европских културних и академских установа. У складу с овом концепцијом, у постколонијалне студије треба укључити или у њима разрадити и друге геокултуролошке појмове, попут „Запад“, „Европа“, „Латинска Америка“, који несумњиво представљају и тек могу представљати значајан део постколонијалних студија (Cabo Aseguinolaza, Rábade Villar 2006: 154-155).

Уколико у оквирима наведене систематизације теоријских блокова разматрамо питања хиспаноамеричке или хиспаноамеричких култура, посматраних у појединачним деловима или у целини, ситуација се знатно компликује услед низа локалних, регионалних и континенталних специфичности које не проналазимо на другим меридијанима. Питања центра и периферије, нас и других, култур- 
не доминације и прожимања, али и сваки покушај анализирања друштвених, историјских или културолошких процеса на тлу Латинске Америке, увек су подразумевали заузимање посебне перспективе због неизоставне комуникације међу различитим заједницама као конститутивним елемената у формирању националног (посебно у постколонијално доба), али и општег, хиспаноамеричког, почев од 19. века па све до дана данашњег.

\section{Транскултурација и кубанска култура: стваралаштво Фернанда Ортиса у контексту студија хиспаноамеричке културе}

Фернандо Ортис Фернандес (Fernando Ortiz Fernández, 18811969), кубански антрополог, историчар, етнолог, криминолог, адвокат, лингвиста, политичар и дипломата, у књизи Кубанско кон-

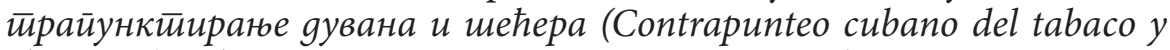
el azúcar), објављеној у Хавани 1940. године, међу првим теоретичарима латиноамеричке културе истакао је значај појма транскултурације (transculturación), који је био у центру истраживања овог аутора приликом анализе капацитета тзв. периферних култура да стварају интеркултурне фузије кроз сусрете и преузимање одређених елемената уместо да некритички или пасивно асимилују културе и(ли) репродукују њихове одабране сегменте (Dagnino 2014: 29). Управо је Ортис инсистирао на специфичности, релевантности и ваљаности употребе појма транскултурације, супротстављајући га мање прецизном и општераспрострањеном појму акултурације, доминантном у америчким антрополошким студијама и теоријским текстовима. Једна од предности појма транскултурације, по Ортису, било је и постојање интегрисане политичке димензије, чије основе проналазимо у пракси тзв. отпора или отпорности свакодневице (Манчић 2014: 347). Појам који се често наводи у Ортисовим есејима, а чије симболичко и метафоричко значење је репрезентативно и од изузетног значаја, јесте ахијако (ajiaco) - типично кубанско јело које се састоји од домородачког тј. америндијанског, европског тј. шпанског, и афричког кулинарског наслеђа. У њему је сједињен свеколики потенцијал фузије и прожимања различитих елемената трију култура које ће допринети настанку хибридне локалне културе, с временом означене као „кубанска култура“. Тако се „кубанство“ процењује по истим мерилима по којима се оцењује квалитет и мешавина укуса кубанског ахијака. Описан процес стапања култура и настанка специфичне хибридне верзије кулинарског ентитета представља уједно еклатантан пример процеса транскултурације (Katoira 2005: 181).

Ортисов живот, време и простор којима је припадао, значајно су условили и његову професионалну активност. Рођен је у Хавани 
16. јула 1881. године, од оца Шпанца и мајке Кубанке, баш у време између ратних сукоба који ће Куби у наредној деценији омогућити независност од Шпаније. Детињство је провео на Менорки, где је завршио прве школе, затим се 1895. године породица сели на Кубу, али после неколико година Ортис поново одлази у Шпанију како би завршио студије права у Барселони и докторат у Мадриду. Други докторат завршава на Универзитету у Хавани 1902. године, а током наредних неколико година бави се дипломатијом и ради у представништвима своје земље у Ла Коруњи, Ђенови, Марсеју и Паризу. У двадесет четвртој години, након више од деценије проведене у иностранству, коначно се враћа на Кубу (Santí 2002: 33). Међутим, због специфичног начина живота, географског поднебља и доброг формалног образовања, мешавине народа и фузије различитих културних екстраката у свом бићу, Ортис је увек према стварности имао одређену критичку дистанцу, те је успевао да из перспективе Шпанца Кубу и кубанску културу посматра као „другог“, али се исто може тврдити и за супротни смер перцепције: да из перспективе Кубанца посматра одлике метрополе. Ова двојност, двоперспективност, објективност „неприпадајућег“ или пак „омниприпадајућег“, значајно утиче на визију аутора о свеколикој стварности и омогућава висок степен критичности и аналитичности у сфери професионалних интересовања и стваралаштва.

Од 1906. године постаје члан значајних кубанских институција у којима ће бити активан у предстојећим деценијама (Audiencia de La Habana, Sociedad Económica de Amigos del País итд). Након што се 1908. године оженио и добио кћер, постаје професор јавног права на Универзитету у Хавани. Тих година активно је учествовао у раду листа Revista Bimestre Cubana, бавећи се уређивањем и доносећи бројне ауторске текстове из различитих области: криминолошке студије, студије о афрокубанским културама, слике обичаја локалног становништва, библиографски прилози о лексикографији, прикази књига и изложби, запажања о политици, о говорима јавних личности и о најразличитијим скуповима. У наредним деценијама уређивао је часописе Surco (1930-1931) и Ultra (1936-1947). Јасно је да Ортис већ око 1910. године, као млад стручњак, ужива огроман углед у академској јавности и у елитним круговима кубанских интелектуалаца (Santí 2002: 37). Убудуће ће овај ерудита бити део не само кубанског политичког живота и већ предлагач конкретних решења, неретко критичар многих негативних промена које ће задесити постколонијално кубанско друштво. Као активан учесник у локалном политичком животу, долазио је у сукоб с властима, а посебно је значајна његова критика владавине Херарда Маћада (Gerardo Machado, 1871-1939), председника Кубе од 1925. до 1933. године, те је морао на неко време да напусти домовину, боравећи у егзилу и активно 
се залажући за своја политичка уверења - либерална, демократска и антитоталитарна. Преминуо је у Хавани 10. априла 1969. године. ${ }^{1}$

Године које су непосредно претходиле објављивању његовог најважнијег текста посвећеног студијама кубанског друштва и културе у ширем смислу обележене су живом стваралачком, критичком и аналитичком делатношћу аутора. Како добро примећује Енрико Марио Санти (2002: 48), Ортис се као енциклопедиста и темељни познавалац националних прилика посветио проучавању кубанске историје и националног идентитета како би пронашао одговоре на бројна питања и могућа решења проблема који су задесили домовину. Чини се да је управо из овакве активности проистекла мотивација за стварање обимног есеја чије ће странице у алегоријском и оригиналном руху бити посвећене кубанској историји, економији, друштву, култури и обичајима.

Објавивши дело Кубанско контирайункиичрағе яувана и шећеpa, Фернандо Ортис се антрополошкој јавности Латинске Америке постепено наметао и профилисао као један од најутицајнијих интелектуалаца оновремене Кубе и региона Кариба. Попут већине својих колега, напустио је земљу ради школовања у Европи, премда се вратио у домовину како би допринео њеном развоју и понудио бројне антрополошке и интердисциплинарне радове и текстове о националној култури. Сместивши Кубу у центар интересовања, бавио се локалном културом, колонијалним системом и постколонијалним друштвом, развојем демократских институција, промоцијом културних организација и издавањем часописа, а његов најважнији допринос подразумева објављивање важних и обимних студија из области криминологије и етнологије (Koronil 1995: ix). Најпознатији је у научним и академским круговима пре свега по антрополошким студијама афрокубанске културе и по развијању специфичне теорије о конститутивној хибридности кубанског етницитета (Chomsky, Carr i dr. 2003: 26). Савремени аутори, који су истраживања посветили друштвеним наукама у најширем смислу, сматрају да је Ортисово дело и истраживачку делатност веома тешко сместити у прецизне оквире, те се питају да ли је он антрополог или социолог, историчар или етнограф, а неретко и припада ли уопште друштвеним наукама. Мултидисциплинарни приступ истраживању и анализи социјалних и културних феномена омогућио је аутору већи избор истраживачких поља и тема (Pumar 2005: 128), те логично довео до истраживачке свестраности, али и интелектуалне, идејне и текстуалне акрибичности.

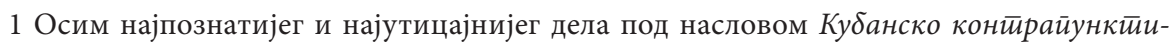
рағе gувана и шећера, од бројних дела овог водећег кубанског интелектуалца 20. века издвајамо наслове: Црни вешии (Los negros brujos, 1906), Поновно освајаюе Америке (La reconquista de América, 1911), Афрокубанско йоgземль: Црни робови (Натра afrocubana: Los negros esclavos, 1916), Исӣорија индокубанске археолоїије (Historia de la arqueología

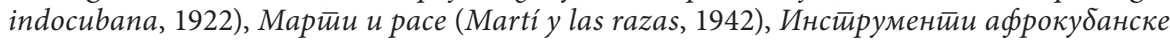
музике (Los instrumentos de la música afrocubana, 5 tomos, 1952-1955) и др. 


\section{Контрапункт, дуван и шећер, транскултурација}


један је од најоригиналнијих и најиновативнијих текстова савремене хиспанске културе, али и неизоставну алатку у рукама свих релевантних стручњака за историју Латинске Америке, а пре свега Кубе. Објављено пре осам деценија, ово дело није имало тада значај који има у скорије време, посебно у савременим студијама културе и антропологије (Santí 2002: 25). Књижевни узор у садржинском, а пре свега структурном смислу, јесте дело шпанског средњовековног писца Хуана Руиса, архипрезвитера из Ите (Juan Ruiz, arcipreste de Ita, око 1283-1351) под насловом Кюиїа о gоброј љьубави (Libro de buen amor, 1330), а очигледан је и утицај кубанског фолклора, народних веровања, молитви, румбе, традиционалног плеса итд. Међутим, у овом контексту можемо говорити о секундарној пародији форме пре́ла, расправе или контрапункта, будући да и текст шпанског писца представља пародирање форме средњовековне теолошке расправе. Стога Енрико Марио Санти (2002: 29) одлази и корак даље тврдећи да је форма дела заправо Ортисов покушај, несумњиво успешан, да пародира форму озбиљног научног, филозофског есеја, сатирично се осврћући на све саставне елементе традиционалног академског текста у коме су размотрени одређени појмови или идеје.

Текст се састоји из два дела: први, по коме је књига и названа, подељен на 15 одељака без редног броја; и други ("Historia, etnografía у transculturación del tabaco habano e inicios del azúcar y de la esclavitud de negros en América"2), знатно обимнији, који садржи 25 поглавља, подељених у мање тематско-садржинске целине. У првом делу текста размотрени су и анализирани елементи присуства дувана и шећера на том простору, док су у другом сегменту књиге изнети закључци и историјски подаци о глобалном значају заступљености и експлоатације дувана и шећера широм света. У овом обимнијем делу текста Ортис настоји да прикаже своју ерудицију, аналитички и синтетички потенцијал, поступно наводећи бројне историјске чињенице и процесе који су током времена утицали на кубанско друштво и економију. Ипак, за теоријско разматрање и уопштавање концепције транскултурације, наведени делови текста имају скроман значај. У првом издању је Ортис други сегмент назвао „пратећа поглавља“ ("capítulos complementarios"), док се касније појављује формулација „додатна поглављ“" (“capítulos adicionales”). Аутор у овој књизи приказује развој кубанске друштвене историје кроз постојање и експлоатацију дувана и шећера, две најважније културе у историји Кубе. Како примећује Фернандо Коромил (1995: ххі), контраст између дувана и шећера у делу је представљен кроз низ бинарних опозиција:

2 „Историја, етнографија и транскултурација хаванског дувана и почеци шећера и ропства црнаца у Америци.“ 
домородачко/страно, тамно/светло, традиција/модерност, јединствено/генеричко, квалитет/квантитет, мушко/женско, мануална производња/масовна производња, независни произвођачи/монополисти, развој средње класе/оштра класна поларизација, урођеничка аутономија/шпански апсолутизам, национална независност/страни интервенционизам, светско тржиште/тржиште САД итд. Ипак, треба напоменути да сви наведени појмови нису подразумевани квалификативи у свакој прилици већ се јављају и међустања, одреднице међусобно условљене различитим појавама или оне у чијој структури проналазимо контрадикторности свакодневице.

Књига је објављена уз Предговор чувеног британско-пољског антрополога Бронислава Малиновског (Bronisław Malinowski, 1884-1942), који је значајно допринео популаризацији Ортисовог рада и ширењу појма транскултурације. Малиновски добро примећује да је наслов књиге инспирисан кубанским фолклором и локалном музиком, а реч contrapunteo представља кубанизам речи contrapunto - контрапункт, који у музици означава технику симултаног појављивања разнородних композиционих делова или гласова у хармонијском следу. Међутим, у контексту ове књиге и наслова може се говорити о контрапункту као о расправи или чак препирци која се води између најмање две супротстављене стране. С обзиром на то да Ортис овом чину даје музички карактер, посреди је форма тзв. музичке расправе или расправе која се одвија музичким средствима (Santí 2002: 26-27). У првом делу књиге доминира симболична форма контрапункта или пре́ла, а циљ је победити противника кроз песничку или музичку виртуозност и умеће. Аутор је на страни дувана и критикује шећер, те се победник зна од почетка, што значајно нарушава принцип неизвесности расправе и представљања коректне аргументације у процесу комуникације и дијалога. Како би се тексту дао призвук алегоријске форме и аутентичности, пољопривредне културе постају ликови: Дон Дуван (Don Tabaco) и Доња Шећер (Doña Azúcar), у складу с богатом шпанском књижевном традицијом током средњовековља и делима која су имала сличну форму, ${ }^{3}$ с том разликом што се Ортис нескривено руга оваквом формалном решењу, заправо пародирајући поступак и елементе шпанске књижевне традиције (Santí 2002: 28). Осим тога, Ортисова критика упућена присуству шећера и експлоатацији шећерне трске део је много шире расправе на националном нивоу, пошто су забележени бројни немили догађаји и злоупотребе производног процеса, чији су протагонисти разне гарнитуре кубанских представника извршне власти. Политичка елита бранила је постојећи систем експлоатације шећерне трске, док су интелектуалци били на страни противника постојећег система (Santí 2002: 62).

3 Пре свега треба напоменути алегоријску битку Дон Карнала и Доња Куаресме из поменутог дела Хуана Руиса под насловом Кюиїа о gоброј тьубави. 
У II поглављу другог дела текста, под насловом "Del fenómeno social de la transculturación y de su importancia en Cuba"4, Ортис јасно развија и објашњава појам транскултурације, коме даје предност у односу на друге сличне термине, посебно акултурације, чија је употреба учестала и неретко идеолошки обојена. Транскултурација је у самој основи кубанске историје будући да је пратећи елемент развоја културе и друштва од првих становника па све до савременог доба. Иако се одвија по фазама, овакав вид фузије подразумева расна, друштвена, културна, обичајна, цивилизацијска прожимања и друге врсте дијалога. По речима Ортиса (2002: 254-255), два су значајна догађаја у кубанској националној историји: 1) долазак Шпанаца на територију Кариба и 2) довожење већег броја афричких робова (пре свега из Сенегала, Гвинеје, Конга, Анголе и Мозамбика) на Кубу и околне територије, што ће подстаћи и заокружити тада развијени процес културног дијалога и размене. Управо појам транскултурације садржи сав дијалошки потенцијал, толико важан у друштвеним и културним кретањима:

Јасно је да појам йранскулимурација на најбољи начин одражава различите фазе у процесу размене елемената две културе у контакту јер он не подразумева само прихватање неке различите културе, што нескривено сугерише англоамерички појам акулииураиија већ нужно подразумева губитак или искорењивање елемената пређашње културе, те би се могао одредити као делимична декултурација, а такође подразумева и последични настанак нових културних феномена, који би се могли назвати неокултурацијом. [...] бйће увек има одлике оба творца, премда се

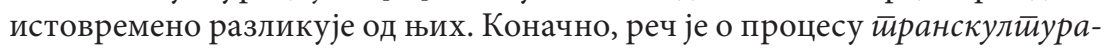
uзије, а овај појам подразумева све фазе параболе (Ortiz 2002: 260, ауторски превод).

Појам транскултурација доводи се у везу пре свега с историјом дувана, а не шећера, будући да шећер на Куби није резултат транскултурације, неког хомогенизујућег друштвеног фактора већ узрок ропства, фактор отуђења. У другом дела текста Ортисовог есеја форма расправе није доминантна унутар сваког поглавља, као у првом делу, већ се принцип контрапункта огледа у спољашњој структурној организацији текста, између целина и поглавља. Расправа, пре́ло, контрапункт постаје метафора или ехо транскултурације, док дија-

4 „О социјалном феномену транскултурације и његовом значају на Куби.“

5 "Entendemos que el vocablo transculturación expresa mejor las diferentes fases del proceso transitivo de una cultura a otra, porque éste no consiste solamente en adquirir una distinta cultura, que es lo que en rigor indica la voz anglo-americana acculturation, sino que el proceso implica también necesariamente la pérdida o desarraigo de una cultura precedente, lo que pudiera decirse una parcial desculturación, $y$, además, significa la consiguiente creación de nuevos fenómenos culturales que pudieran denominarse de neoculturación. [...] la criatura siempre tiene algo de ambos progenitores, pero también es distinta de cada uno de los dos. En conjunto, el proceso es una transculturación, y este vocablo comprende todas las fases de su parábola." 
лог о националној економији сличнији, до одређене мере, једном специфичном моделу историјске дијалектике. Сукоб мишљења или расправа саставни су део и нужни елемент процеса транскултурације, тј. свих оних важних елемената који одређују кубански идентитет и „кубанство“ (“cubanidad”) (Santí 2002: 80).

У Предговору Ортисовој књизи Малиновски се такође присећа разговора с аутором и ентузијазма због увођења неологизма „транскултурација“, који је требало да замени постојеће појмове у употреби: „промена културолошке матрице“, „акултурација“, „културна разуђеност или нестајање културолошког језгра“, „културне миграције или културолошке осмозе“ итд. (Malinowski 2002[1940]: 124). Након одушевљења, британско-пољски антрополог обавезао се аутору да ће се здушно залагати за употребу тог неологизма у свим текстовима који буду настајали у његовом опусу, а разумевање и уважавање два стручњака потврђено је управо његовим уводним текстом. Малиновски критикује постојећи израз acculturation, присутан у англосаксонској научној средини, пре свега јер је етноцентричан и има моралистичко значење. У складу с поставкама које овај појам подразумева, имигрант заправо треба да се прилагоди доминантној култури, при чему се његова изворна култура сматра варварском, паганском или дивљом, те само прилагођавањем и одбацивањем елемената сопствене културе може се интегрисати у обрасце западне културе, чије су карактеристике по погрешном предубеђењу увек одраз цивилизације и напретка. Зато Малиновски (2002[1940]: 125) сматра да би једини примерен начин интеракције био постојање и стварање атмосфере непрестаног културног дијалога, међусобне промене културних образаца кроз процес комуникације и мешања, у коме једна култура нешто даје другој истовремено преузмајући од ње елементе и саображавајући их сопственом обрасцу или традиционалном културном моделу. То укратко подразумева појам транскултурација. У овом процесу не настају само нове културе, промењене и прилагођене, већ потпуно нова културна стварност, једна нова и сложена реалност без механички спојених елемената који би чинили мозаик, те нови, независни и оригинални облик културе. Тако обе културе у дијалогу постају активне учеснице у процесу, а не пасивни објекти у предвиђеним и предодређеним улогама културолошке доминације или субмисивности.

Дакле, транскултурација подразумева две фазе: 1) губитак елемената постојеће културе (декултурација); и 2) настанак нове културе (неокултурација). У свом обимном тексту Ортис, чини се, подједнако разматра и развија оба вида проблема транскултурације (Коромил 1995: хxvi).

Ортисов текст у целини представља неку врсту пионирског и иновативног архетипа будућег низа економских студија које су настале током 20. века по истом методолошком обрасцу: анализа 
присуства, историје узгоја пољопривредне културе на одређеном тлу како би се објаснили историјски, друштвени и културолошки процеси, те предности и недостаци постојећег привредног система. Читалац у овом делу перципира форму пре́ла или расправе, бинарне опозиције два става или гледишта, као што посматра елементе свакодневице: попут привида, неке врсте лажне и отуђене свести. Иза или након успеха, хармоније и ритма живота који условљавају две супротстављене пољопривредне културе, дувана и шећера, може се открити права историја: транскултурација и процес социјалног прожимања (Santí 2002: 78). Такође, принцип контрапункта и транскултурација деле важну заједничку одлику: антиномијску, опозициону структуру, док сваки појам у себи садржи спој два различита феномена, премда на различите начине повезана. У форми пре́ла или контрапункта, дуван и шећер воде симболичку расправу, испитују међусобне разлике, иако се не наводе очигледне непремостиве супротстављености. Стога форма контрапункта није у потпуности дијалектичког карактера у овом делу. С друге стране, процес транскултурације то несумњиво јесте: антиномија се заснива на културним разликама и разрешава се у синтези која се значајно разликује од изворних полазишта и одлика̂ појединачних елемената скупа (Santí 2002: 80).

\section{Закључак}

Рецепција појма транскултурација је на шпанском говорном подручју била двојака. Међу антрополозима и у традиционалним круговима културолога била је посве негативна, док је овај појам солидно прихваћен у контексту студија културе, а поготово после објављивања студије Прийовеgачка йранскуличурација у Латиинској Америци (Transculturación narrativa en América Latina, 1982) уругвајског критичара Анхела Раме (Ángel Rama, 1926-1983) (Santí 2002: 92). Међутим, Рама анализу корпуса и употребу појма транскултурације искључиво прилагођава сфери књижевних студија (стваралаштво Хосеа Марије Аргедаса (José María Arguedas, 19111969)), бранећи теорију о супериорности бројних видова домородачке културе у сусрету и фузији с европским културним екстрактима. Убрзо појам транскултурације неретко бива у пракси замењен другима, попут појмова хетерогености или хибридности, карактеристичним за спектар теоријских концепата постколонијалне теорије и критике.

Дело Фернанда Ортиса Кубанско конӣрайункиичране gувана и шећера несумњиво је један од најутицајнијих есеја о хиспаноамеричкој култури и важан елемент у сваком озбиљнијем проучавању антрополошке, друштвене и економске историје Кубе и Латинске Америке. 
Изненађује до које мере је англоамеричка и европска антропологија у деценијама након објављивања дела, а и до дана данашњег, у бројним разматрањима транскултурације, акултурације, интеркултурације, неретко прећуткивала име Фернанда Ортиса, те порицала његов несумњиви значај и утицајност у сфери савремених терминолошких одређења студија културе и постколонијалне критике. Ситуација је била нешто повољнија у кубанским и шпанским интелектуалним круговима, премда ни у тим срединама, све до последњих година, не проналазимо конзистентно интересовање за његов рад и систематско проучавање свих важних поставки које ће усмерити студије латиноамеричке културе.

Овај обиман, систематичан и јединствен есеј до одређене мере преиспитује границе појмова „центар“ и „периферија“, „ми“ и „други“. Ипак, не треба занемарити специфичности и јединствености латиноамеричке културе и кубанског поднебља, будући да контекст потенцијалног проучавања транскултурности може у значајној мери бити различит у односу на слична разматрања на другим меридијанима. У оквирима савремених постколонијалних студија и студија културе значај овог есеја проналазимо пре свега у систематичној разради концепције специфичне културе засноване на додирима, комуникацији и асимилацији, као нужно двосмерним појавама, без основа или простора да се једна култура сматра „централном“, „снажнијом“ или „доминантнијом“, те да култура колонизатора сматра себе супериорнијим обликом постојања од културе колонизованих. Основна идеја књиге очигледно је била да се у алегоријском кључу покаже да у једном динамичном облику тзв. транскултурације, у појавности савременог света, треба истовремено да постоји стабилност, али и доза тињајућег насиља, непрестана игра моћи и њених друштвених последица. Коначно, овај текст нам омогућава, између осталог, да сагледамо сву сложеност игре обмане, контроле и моћи у процесу стварања или разградње културних формација.

\section{ЛИТЕРАТУРА}

Dagnino, Arianna. "Transculturalism and Transcultural Literature in the

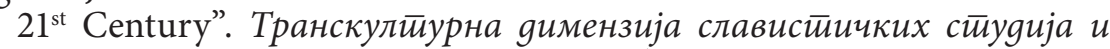

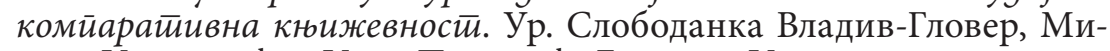
лена Илишевић и Игор Перишић. Београд: Институт за књижевност и уметност, Годишњак XXVII, Серија Ц, Теоријска истраживања, Књига 17, 2014. 27-40.

Cabo Aseguinolaza, Fernando y María do Cebreiro Rábade Villar. Manual de Teoría de la Literatura. Madrid: Editorial Castalia, Colección Castalia Universidad, 2006. 
Catoira, Patricia. "Transculturation à la Ajiaco: A Recipe for Modernity". Cuban Counterpoints - The Legacy of Fernando Ortiz. Eds. Mauricio A. Font and Alfonso W. Quiroz. Lanham, Boulder, New York, Toronto and Oxford: Lexington Books, 2005. 181-191.

Coronil, Fernando. "Introduction. Transculturation and the Politics of Theory: Countering the Center, Cuban Counterpoint". Cuban Counterpoint, Tobacco and Sugar. Fernando Ortiz. Translated from Spanish by Harriet de Onís, Introduction by Bronislaw Malinowski, Prologue by Herminio Portell Vilá, New Introduction by Fernando Coronil. Durham and London: Duke University Press, 1995. IX-LVI.

Malinowski, Bronislaw. "Introducción". Contrapunteo cubano del tabaco y el azúcar (Advertencia de sus contrastes agrarios, económicos, históricos y sociales, su etnografía y su transculturación). Fernando Ortiz. Edición de Enrico Mario Santí. Madrid: Cátedra, Letras Hispánicas, [1940] 2002. 123-133.

Манчић, Александра. „Вићења транскултурне димензије компаратистичког аспекта славистичких студија из преводилачког угла.“

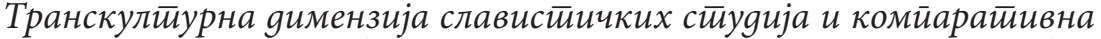
къижевноси. Ур. Слободанка Владив-Гловер, Милена Илишевић и Игор Перишић. Београд: Институт за књижевност и уметност, Годишњак XXVII, Серија Ц, Теоријска истраживања, Књига 17, 2014. $345-368$.

Ortiz, Fernando. Contrapunteo cubano del tabaco y el azúcar (Advertencia de sus contrastes agrarios, económicos, históricos y sociales, su etnografía y su transculturación). Edición de Enrico Mario Santí. Madrid: Cátedra, Letras Hispánicas, 2002.

Pumar, Enrique S. "Economic Sociology and Ortiz's Counterpoint". Cuban Counterpoints: The Legacy of Fernando Ortiz. Eds. Mauricio A. Font \& Alfonso W. Quiroz. Lanham, Boulder, New York, Toronto and Oxford: Lexington Books, 2005. 127-138.

Santí, Enrico Mario. "Fernando Ortiz: contrapunteo y transculturación". Contrapunteo cubano del tabaco y el azúcar (Advertencia de sus contrastes agrarios, económicos, históricos y sociales, su etnografía y su transculturación). Edición de Enrico Mario Santí. Madrid: Cátedra, Letras Hispánicas, 2002. 25-103.

Chomsky, Aviva, Barry Carr and Maria Smorkaloff (Eds.). The Cuba Reader (History, Culture, Politics). Durham and London: Duke University Press, 2003.

Šušnjić, Đuro. Teorije kulture (predavanja). Beograd: Zavod za udžbenike, 2015.

Fundación "Fernando Ortiz":

$<$ http://www.fundacionfernandoortiz.org/index.php> 15.09.2018. 
Vladimir Karanović

The Contemporary Cuban Cultural Studies: Fernando Ortiz and Transculturation

\section{Resume}

At the very basis of the Western European cultures, and as of recently of Eastern cultures too, lies the process of meeting, communication, mixing, permeation and mutual change. Apart from the European continent, this phenomenon is especially present in the cultures that stood, in the political and social sense, as constituent parts of the colonial system, in the relation of domination and submission. In the process of contact of different cultures, some elements are often assimilated selectively, which lends them new forms, new meanings or different symbolic functions.

The Cuban anthropologist, historian, ethnologist, criminologist, lawyer, linguist, politician and diplomat Fernando Ortiz Fernández (1881-1969), being among the first theorists of Latin American culture, in his book Cuban Counterpoint Tobacco and Sugar (1940) highlighted the importance of the concept of "transculturation". This concept was at the center of his research of the so-called capacity of "peripheral" cultures to create an intercultural fusion through encounters and take in certain elements, as opposed to the free or passive assimilation of entire cultures and/or only some cultural elements. Transculturation is the basic element of Cuban history, since it has accompanied the cultural and social development from the first settlement to the present day. Although it is being carried out in phases, this type of fusion implies the mixture and permanent racial, social, cultural etc. dialogue.

This extensive, systematic and unique essay partially examines the limits of the concepts of contemporary postcolonial criticism. The basic idea of the book was, obviously, to show, using a dynamic form of the so-called "transculturation", that there must be stability in the modern world, but also a dose of reduced violence, a constant game of power and its social consequences. This paper also allows us to observe the complexity of deception and the game of power in the process of creating or degrading cultural formations.

Keywords: Fernando Ortiz, transculturation, Cuban culture, Ethnographic Studies, Latin American Cultural Studies

Примљено: 6. 6. 2019.

Прихваћено: 15. 3. 2020. 